TANULMÁNYOK 2020/1. Bölcsészettudományi Kar, Újvidék

STUDIJE 2020/1. Filozofski fakultet, Novi Sad

STUDIES 2020/1. Faculty of Philosophy, Novi Sad

ETO: $81^{\prime} 23$

ORIGINAL SCIENTIFIC PAPER

616.89-008.444.7

DOI: $10.19090 / \mathrm{tm} .2020 .1 .47-63$

Submitted: 21 January, 2020

Accepted for publishing: 1 April, 2020

\author{
Roland-Attila SZABÓ \\ Partium Christian University \\ Department of Languages and Literatures \\ Oradea, Romania \\ rolandszabo@partium.ro
}

\title{
FACTORS AND CONDITIONS THAT INFLUENCE THE PERCEPTION OF OFFENSIVE HUMOR
}

\section{Faktori i uslovi koji utiču na percepciju uvredljivog humora}

\section{A sértő humor értelmezését befolyásoló tényezők és feltételek}

The study is derived from a larger study, namely the author's $\mathrm{PhD}$ dissertation, and it gives an overview of and illustrates the most essential factors that maneuver utterances into being perceived as humorous and/or offensive in the context of performed, edgy stand-up comedy. The paper introduces basic humor and offensive humor theories as well as certain pragmatic mechanisms that lie beneath the process which starts with the utterance and ends with the perlocutionary effect on the audience. The study elaborates on offensive humor theories, conventions of stand-up comedy, pragmatic concepts, the contrast between offensiveness and immorality, which is all complemented by a brief psychological perspective, linking people's reactions to the notion of harm and one's level of self-esteem. The pragmatic insight into the factors that make offensive humor function points at the necessity of strong, non-conventional, and complex stimuli, perceived and comprehended by the audience, based on which the offensive layer can be constructed.

Keywords: offensive humor, stand-up comedy, pragmatics

\section{Introduction}

The role of humor from a social point of view is generally thought to induce laughter, arouse good mood, and - an important point in stand-up comedy lighten certain situations. The present study introduces a few from the myriad factors and pragmatic mechanisms that lie behind people's reactions to offensive stand-up comedy humor in order to reveal the conditions for humor perception 
as well as offense-taking. Humor theories such as the incongruity theory, the hostility theory, the release theory, the semantic script-base theory, the general theory of verbal humor as well as offensive humor theories such as the attitudinal endorsement theory, the merited response theory, and the benign violation theory will help explain how these roles function within a stand-up comedy framework, and how they can be extended when subjects deemed inappropriate for joking are introduced by comedians.

\section{Key to transcription convention}

Studies of corpus analysis that analyze conversations, stand-up comedians, and sit-com language have been consulted in search for a commonly used, pre-established system of symbols. It is Gail Jefferson's (2004) set of transcript symbols that finally led to a functioning system for this study. However, the set has been complemented with some other conventions observed in studies on audience response (e.g. Paul Mcllvenny 1993), resulting in the set of symbols presented below.

(.)

]

-uh- -uhm- -aw-

CAPS LOCK

(h)

$\mathrm{H}$

$-\mathrm{h}-$

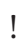

(c)

C

(b)

B

(g)

G transcriber's notes

micropause (less than 1 second)

seconds of a pause

indicates the point of overlapping onset

indicates the point where overlapping ends

speech disfluency, filler

louder than usual or shouting

0.5 seconds of isolated laugh

0.5 seconds of laughter

laugh embedded in the comedian's speech

sudden burst $(! \mathrm{H}=$ of loud laughter; $! \mathrm{B}=$ of loud booing; $! \mathrm{C}=$ of loud clapping)

0.5 seconds of isolated clap

0.5 seconds of clapping

0.5 seconds of isolated boo

0.5 seconds of booing - showing dislike /disagreement / intolerance

0.5 seconds of isolated groan

0.5 seconds of groaning - showing astonishment / disgust / indignation 


\begin{tabular}{ll}
$(\mathrm{w})$ & one isolated whistle \\
$\mathrm{W}$ & 0.5 seconds of whistling \\
$\mathrm{X}$ & 0.5 seconds of cheering \\
$(\mathrm{x})$ & 0.5 seconds of isolated cheer \\
(s) & 0.5 seconds of isolated shouts/inaudible speech (from the \\
$\mathrm{S}$ & $\begin{array}{l}\text { audience) } \\
\uparrow \downarrow\end{array}$ \\
$=$ & upward and downward intonation \\
$><$ & no pause between utterances \\
$<>$ & slower utterance \\
\hline & particularly stressed utterance \\
& 0.5 seconds elongation
\end{tabular}

\section{Humor Theories}

Incongruity theory is the first to emerge in linguistics-based humor research as it is fundamental in further script-based theories. Humor results from the difference between what is expected to happen based on the first script, and what actually happens when the second script is revealed. The two conflicting scripts bring along the element of surprise, and the sense of ambiguity. By recognizing the incongruity of the two scripts that clash, discrepancy is created, which results in laughter or other manifestations sourced from humorous interpretation. Technically speaking, "a large amount of nervous energy, instead of being allowed to expend itself [...], is suddenly checked in its flow. The excess must discharge itself in some other direction [...]" (Raskin 1985, 31). The other direction is through laughter or similar reactions of the recipient. Consider one of Jimmy Carr's (2009) jokes:

JIMMY < dog excrement can blind a child $>$

CARR but it's much easier (.) > just to use a finger $<$ ((showing index-finger $))$ AUDIENCE HHHh

The first half of the joke is a 'warning' script, which is introduced by the comedian in a way that it actually sounds credible. It sounds similar to the result of a scientific research, and although it seems strange, it is perfectly plausible. Not knowing the chemical composition of dog excrement and details of such conclusion that might support the theory, the statement is taken seriously, and the audience may even recall memories when their children might have been 
exposed to this potential danger. The 'warning' script would anticipate a moral or some sort of conclusion if it were part of an everyday conversation, or a punch line in comedy, based on an unexpected conclusion. However, the joke reinterprets the 'warning' script and turns it into an unusual 'advice' script, in which dog excrement is mentioned as a possible means for someone looking for solutions to blind a child. The second sentence confirms this by offering an easier method. The two situations overlap, incongruity occurs, and the mere realization of the incongruity results in the previously mentioned discharge of nervous energy: laughter.

Hostility theory goes by different names, among which superiority theory must also be listed for better understanding. The theory has its roots in ancient history, it is retraceable to Plato and Aristotle, and it has at its core the "sudden glory" as Thomas Hobbes (quoted in Allen 1998, 10) put it that arises from the immediate realization of one's superiority. The theory has more to do with malice, envy, aggressiveness targeting faults of other people with the purpose to disparage, ridicule, and humiliate them. Aristotle describes it as the "enjoyment of the misfortune of others due to a momentary feeling of superiority or gratified vanity that we ourselves are not in the predicament observed" (quoted in Allen 10). Suls writes about disparagement theory, claiming that "we laugh at other people's infirmities, particularly those of our enemies" (quoted in Raskin 1985, 37). This must explain why there are countless jokes about politicians, mothersin-law, policemen, wives and husbands... etc. The long experience of dishonest politicians, annoying mothers-in-law, and people's constant struggle to dominate their partners create a desire for superiority. A joke that disparages any people one wishes to see inferior results in one's joy out of malice, and so, the feeling of sudden superiority most often manifests in laughter. To illustrate hostility theory, the following joke has been included, which was taken from one of Jim Jefferies' (2014) stand-up routines:

JIM JEFFERIES I would love to be gay (.) I'll tell you why (.) 'cause I'm a man's man $(($ amused/jovially $))<$ I LIKE MEN $>$ (.) $<$ MEN LIKE ME $>$

AUDIENCE $\quad(\mathrm{x})$

JIM JEFFERIES ((amused/jovially)) WE LIKE EACH OTHER

AUDIENCE $\quad(\mathrm{hh})$

JIM JEFFERIES ((amused/jovially)) <I HATE WOMEN>

AUDIENCE hhhh[hh]

[cc]

JIM JEFFERIES < <WOMEN HATE ME> 
AUDIENCE Hhhh

JIM JEFFERIES WE -h-HATE each other.

AUDIENCE $\mathrm{Hh}$

JIM JEFFERIES ((factually)) the only reason I couldn't be gay is (.) cause I could never fuck a man $\downarrow$

(1.0) 'cause I could never fuck something that I respect

[((smiles) $)][(($ laughs with satisfaction $))]$

AUDIENCE [!GGGG] $\mathrm{xxcc}[\mathrm{cc}(\mathrm{x}) \mathrm{cc}]$

[!HHHh]

The misogynistic joke divides the audience into inferior (women) and superior (men) members according to the hostility theory. Men cheer, clap, and laugh at the joke since the joke glorifies men, placing them above women, claiming that men are worthy of respect and women are not. Momentarily, the punch line of the joke causes men to feel dominant, and while this might not be the case in their real lives with their partners, it gives them some sort of victory over women. Obviously, the men cheering may not hate women or their partners in real life, though they might hate losing arguments with women, and the "sudden glory" caters to their egos. Women are less likely to appreciate the joke as they are members of the disparaged group.

Release theory is concerned with the feeling of liberation and relief. It is about releasing tension and eliminating nervous energy. This occurs when taboo topics are introduced or topics inappropriate for open discussions emerge among people. Obviously, the best example is sex and everything related to it. Raskin claimed the following:

Every aspect of our existence, from the most trivial to the most profound, is molded by group expectations. It should come as no surprise, then, that the sight of a comic ignoring conventions excites us... because it provides us, vicariously, a moment of freedom from the prisons of our adjustments (39).

Discussing taboo subjects in the open is such a moment of freedom. Freud proposed the term "tendentious jokes" for the opposite of innocent jokes, which reveal either aggressiveness or obscenity and exposure. Obscene jokes and exposed taboos help overcome certain inhibitions and allow one to satisfy certain desires, shameful thoughts otherwise considered socially unacceptable. The liberation itself results in laughter which removes or replaces the nervous energy. 
The semantic script theory of humor (SSTH) is a linguistic theory introduced by Raskin that accounts for the speaker's competence of humor. Raskin $(1985,99)$ sums up the main hypothesis of script-based humor by analyzing a sample joke.

A text can be characterized as a single-joke-carrying-text if both of the following conditions are satisfied: [ $\mathrm{t}$ ] he text is compatible, fully or in part, with two different scripts [and] [t] he two scripts with which the text is compatible are opposite. The two scripts with which some text is compatible are said to overlap fully or in part in this text.

The script is a cognitive structure internalized by the native speaker and it represents the native speaker's knowledge of a small part of the world. Every speaker has internalized rather a large repertoire of scripts of "common sense" which represent his/her knowledge of certain routines, standard procedures, basic situations, etc. (Raskin 1985, 81).

The general theory of verbal humor (GTVH) is in fact a revised version of SSTH. Attardo $(2000,22)$ explains that the semantic approach has been broadened into a linguistic approach which entails "textual linguistics, the theory of narrativity, and pragmatics, broadly conceived." This broadening adds five Knowledge Resources (KR) in addition to script opposition explained by the SSTH. These are: the language, the narrative strategy, the target, the situation, and the logical mechanism.

\section{Offensive Humor Theories}

When it comes to explaining offensive humor, a very complex set of factors and aspects are to be considered, preferably from several perspectives. These theories analyze the offensive aspect of humor, and they might be found fallacious or might bring greater understanding as to what is meant by offensive and based on what criteria offensive jokes are seen as humorous.

Aaron Smuts' (2009) study on the ethics of humor analyzes what moral significance there is behind finding a sexist or a racist joke funny. He does so by looking into certain theories, one of which leads us to Ronald de Sousa's (2002) attitudinal endorsement theory. De Sousa examines certain ethical dimensions of his so-called "phthonic laughter," which is laughter out of malice or envy. His hypothesis holds immoral assumptions about the perceiver's character. De Sousa argues that in order to find an offensive joke funny, one must share the supposed assumptions that the joke calls for. By this rationale, misogynistic jokes can be considered humorous to people who endorse certain misogynistic attitude. Smuts (2009) disagrees with the assumption, and argues that one only 
needs to assume a misogynistic attitude in order to find the joke funny, it is not necessary to endorse it.

George Carlin, Jim Jefferies and Jimmy Carr, famous stand-up comedians, have their atheism in common, and as a result, all three have an abundance of jokes that either mock, ridicule or simply attack religion and religious people. Based on the recorded audience response, one can deduce if a certain belief or principle is shared by the audience or not. Atheism is more likely to be shared among these three comedians' members of audience. Consequently, when antireligious jokes are told by the comedian, the audience endorse the attitude, which definitely increases the chances of such jokes to be viewed as humorous.

However, there are plenty of other situations to contradict Sousa's theory. It would be unwarranted to assume that someone is attracted to underage girls, merely by finding a pedophilia joke funny. Smuts argues that sometimes "offense trails behind amusement. [...] in some cases we may find a joke funny but wish we had not" (Smuts 2009, 340). Nothing indicates that it is inevitable to endorse the particular attitude introduced by the joke to find an offensive joke funny.

The merited response theory was developed by Gaut (2007), and has even more to do with the ethical aspect of humor. Gaut believes that judgments of humor are normative, and jokes that cross certain boundaries do not merit amusement. Gout argues that "moral shortcomings can count against the humorousness of a joke and, as a result, some jokes are not funny-even if some people think so" (Gaut 2007, 243).

Humor being treated as a normative concept, one will have to assume that what people find humorous does not always match with what they are supposed to find humorous. When somebody says "that's not funny," Smuts $(2009,341)$ claims, they really mean "you should have had a different reaction." However, this kind of unilateral normativity is elusive and subjective, and has more to do with personal censure than anything else. Merited response theory tries to establish a culture-dependent moral compass that follows certain moral principles, and the jokes going beyond the established ethical code should not be considered humorous by anyone. However, merited response theory might add something to the explanation why people do not find certain jokes funny. It also might explain why journalists who attacked George Carlin and Jim Jefferies for joking about rape said that they should not joke about it (Fenton 2016). Those journalists see no humor in such jokes because they consider that rape is far too serious an issue to be connected to any sort of amusement. Consequently, they treat humor as a normative concept.

Unlike the previous two theories, which have more to do with the ethical approach, Thomas Veatch's (1999) theory (also known as "benign violation" 
theory) concentrates on providing an applicable formula on how offensive humor works, and what conditions lead to their perception as humorous.

In a nutshell, Veatch (1999) claims that humor occurs when it appears that things are normal $(\mathrm{N})$, but that perception simultaneously clashes with the feeling that something is wrong. So humor takes place when someone briefly feels "bad about something (a violation $=\mathrm{V}$ ) and then [makes] oneself feel that that very thing is actually okay (N)" $(1999,3)$. He claims that "[1] evity can arise from this simple emotional mixture alone." It is important to state that both $\mathrm{N}$ and V are "views of the situation" carrying "emotional or affective content" (Veatch 1999, 3).

Firstly, in situations where nothing seems wrong, humor perception will be absent. What "wrong" means here is up to the perceiver's subjective and affective moral commitments. Consequently, the same situation might not seem wrong from another perceiver's point of view, making humor perception highly subjective. Secondly, if the perception of a situation being normal is missing, humor will also be absent. If there is nothing in the joke that seems normal $(\mathrm{N})$, a mere violation $(\mathrm{V})$ of moral, for example, will not be funny. An exceptionally strong commitment to the moral violated in the joke will also stamp out the $(\mathrm{N})$ interpretation. Furthermore, as we know that surprise, conflict and ambiguity have a crucial role in humor, $(\mathrm{N})$ and $(\mathrm{V})$ have to occur at the same time for the situation to be perceived as funny.

Veatch (1999) suggests that people are endowed with a rich cognitive and emotional system of opinions, which establishes an individual proper order of the social and natural world, and this set of principles can be referred to as morality. Whenever this set of principles is violated, affective responses emerge, such as getting offended, or anger, with the goal of restoring the situation to its normal state. This affective response might as well be laughter.

As opposed to de Sousa's (2007) attitudinal endorsement theory, which claims that in order to laugh at a sexist joke, one must, to some extent, endorse sexist attitude, Thomas Veatch (1999) claims that one only has to feel less attached to a principle in order to find it funny. One does not necessarily have to be sexist or hold sexist views, one only needs to see the violation of the principle less affectively.

\section{Immoral vs. Offensive}

The concept of 'immoral' can be universally defined as 'conflicting with generally or traditionally held moral principles' or 'violation of moral laws, norms or standards' (merriam-webster.com). As far as society is concerned, 
the rules may vary from culture to culture, and therefore, joking about certain subjects can result in different degrees of immorality depending on the cultural context in which the joke is told. Having analyzed English-speaking stand-up comedy, and audiences who understand the conventions of such a context, the study should be viewed within the restrictions of Western culture in general.

Considering a joke "offensive" is a far more subjective verdict than deeming it "immoral," and it has to do with someone's personal attitude towards moral issues, while "immoral" is based on socially accepted conventions in which a society or community lives in. A joke, Lasky $(2015,10)$ argues, does not necessarily need to be considered offensive to be considered immoral. She states that racist white people telling racist jokes to each other will probably result in offending no one; however, they might agree that their activity is regarded as immoral in society. They might believe that telling racist jokes is not offensive (to them), but they cannot deny the immoral nature of their activity, for mere personal opinion is not sufficient to establish laws of immorality in a society, there has to be a consensus on what is immoral. On the other hand, a joke may not have to deal with norms of society per se to be considered immoral. A joke told to deliberately hurt someone's feelings is bound to be immoral; if the statement - not immoral in other contexts - intentionally hurts someone, it becomes a face-threatening act, which is an attack on the positive social value a person that he effectively claims for himself. Thus, the person is engaged in using negative impoliteness, a term used in Pragmatics to refer to scorning, ridiculing, frightening someone directly (as opposed to positive impoliteness, which refers to using taboo words, ignoring or denying common ground with a person, or in other words, a less direct way of attacking someone), and consequently, the behavior is considered immoral. Furthermore, jokes can offend without being considered immoral by society. What is considered offensive tends to be a primarily personal, subjective issue, which means that one can take offense at something that was not meant to offend. Consequently, the comedian cannot be labeled as immoral simply because someone gets offended, unless his statement, or his intention behind the statement, is regarded as immoral by social norms in society - and not by an individual.

Acceptance of immorality to whatever extent, Lasky (2015) suggests, means that the accepter recognizes a previously encountered attitude and is able to recall some truth from reality upon which the joke is built. Without the capability to find the common subset, the joke cannot result in humor perception. As Lasky $(2015,12)$ put it, "if someone made a racist joke about how white people love oranges, nobody would find this joke particularly funny. In this way, jokes need to work in accordance with the way we experience the world in order to be funny." 
As for their role in stand-up comedy, immoral jokes have the power to intensify the audience's reactions, which inherently creates greater impact, because the tension caused by them has to be released, and the moral dilemma has to be solved. Therefore, jokes that break the rules and put the audience on the edge will receive louder response than the ones that do not cross moral boundaries. Comedians constantly play with these boundaries and push the limits to keep the audience alert, and it is the audience that can draw the line between what is still acceptable and what is not. But the audience as a whole rather than individual members of it, as there are always punters who take offense.

Offense, on the other hand, is very necessary. A stand-up routine that does not offend anyone whatsoever will not be powerful enough. Audiences demand challenge because "[o]ffense is an emotional wallop, and can therefore force people to re-evaluate their beliefs and see things in a new way" (Lasky 2015, 14). The stand-up comedian Jimmy Carr suggested that a good joke is one that makes one laugh, but laughing about it makes one feel like a horrible person. This statement of his confirms Lasky's view, and refers to the subset of truth that punters will find in an offensive joke. If it was endorsement, as De Sousa (2007) suggested, why would they feel horrible about something they approve of? They recognize immorality in the joke, and that under conventional circumstances it would be immoral to laugh about it, so the feeling of a horrible person comes from being able to assume the point of view of the offender. In other words - in accordance with Thomas Veatch's (1999) theory - they manage to understand why the joke is offensive, and manage to distance themselves enough from the violation in order to find it funny, but since there is no real endorsement, the inner conflict between disapproval and humorous perception results in a powerful response.

\section{The Need for Strong Stimuli}

The semantic script-based theory and the incongruity theory provide explanation for humor that is based on types of ambiguity. Merely being hostile to a target group may not be enough to generate humor. The desired effect is achieved by different factors, especially when they occur at the same time. It has been noticed that the more stimuli one is subjected to, the more humor is created, provided the complexity of channels through which humor is transmitted can be understood. By studying the mechanism of puns, more can be revealed about the complexity of certain jokes, and analysis becomes possible. Jokes based on puns are predestined to result in humor. The incongruity caused by the sudden appearance of the second script with the help of a script-switch trigger calls for 
a restoration of order in the perceiver's mind. Rebuilding the isotopy of the text by working out the new meaning of the signifiant requires an effort on the part of the audience, and as soon as the puzzle is solved, the absurdity is revealed, humor perception becomes available, and laughter restores order. In the one-liner "I make my own vegetables. (Pause). I've got a hammer." "vegetables" is the signifiant carrying both meanings needed for the two scripts, and "hammer" is the script-switch trigger that reveals the unexpected meaning of the signifiant, that is, "people being in a vegetative state."

On the other hand, humor develops, and people's minds are well conditioned to look for puns in language, especially in the context of stand-up comedy, and therefore, puns can become predictable. However, offensive stand-up comedy is still something of a novelty, and considered edgy, which is why puns are rooted in taboos. Immoral puns are hostile (hostility theory), create tension (release theory), and are based on ambiguity (script-based / incongruity theory), which is why humor is perceived on many levels.

Palmer $(1994,162)$ writes about the old-world "pratfall gags" that characterized the Hollywood silent farce carrying minimal stimulus for a modern audience. Nowadays, the more stimuli are required to understand the joke, the more humorous the joke will become - provided the perceiver is able to infer the intended force behind the joke.

By studying speech acts, utterances can be analyzed in context and can become transparent in that they reveal the elements that affect meaning. Utterances have illocutionary force (the conventional force associated with an uttered statement) and perlocutionary effect (the effect the statement has on the audience). Comedians play with that force so that they attain the desired effect. Primarily, jokes inherently have to violate certain rules of human communication, and it turns out that offensive comedy, as opposed to innocent jokes, violates a series of rules at the same time. As said before, the more stimuli are given to the perceiver, the more channels open up through which humorous force can be transmitted. Consider the following extract from one of Jim Jefferies' (2014) stand-up routine.

1. JIM JEFFERIES

2.

3. AUDIENCE

4. JIM JEFFERIES

5. AUDIENCE what happens if your girlfriend's away on work (.) and the dog dies?

you go off (.) you buy another dog [(1.0) that looks] similar to the [original dog]

[hhhh] [hh]hh

try to pass it off as the same dog

Hhh 
6. JIM JEFFERIES what happens if your girlfriend's away on work (.) <and the baby dies?>

7. AUDIENCE Hhhhhh

8. JIM JEFFERIES very ha:::rd

9. AUDIENCE Hhhh

10. JIM JEFFERIES to get a baby that looks exactly the same=

11. $=$ in the short period of [time that you have]

12. AUDIENCE [hh]hhhh

13. JIM JEFFERIES easier if you're black or Asian

14. AUDIENCE !HHHHh[hhhhh]

15. $\quad[\operatorname{ccccc}] \operatorname{cccc}$

16. $[\mathrm{xx}] \mathrm{x}(\mathrm{x})$

17. JIM JEFFERIES [((irritated)) Boston (.) no ((annoyed)) no::] (.)

18. AUDIENCE [XXXXXX]

19. [CCCCCC]

20.

21. JIM JEFFERIES $[(($ angrily $))>\mathrm{NO}<(($ fed up $))$ shut up $]$

22. AUDIENCE $[\mathrm{XXXX}] \mathrm{hh}$

23. $[\mathrm{cccc}]$

24. JIM JEFFERIES I WILL NOT PUT UP WITH RACISM AT MY SHOWS [(.)] OKAY?

25. AUDIENCE $[(\mathrm{x})]$

26. $\mathrm{Hh}$

27. JIM JEFFERIES [I'M NOT SAYING,CAUSE THEY <LOOK THE SA:ME>]

28. AUDIENCE $[(\mathrm{c})(\mathrm{x})(\mathrm{x})(\mathrm{x})]$

29. JIM JEFFERIES I'm saying, cause they're easier to purchase

30. AUDIENCE !HHH[HhhXXXxxx]

31. $[\operatorname{coccccccc}]$

32.

33. JIM JEFFERIES [if Angelina Jolie and Madonna] have taught us anything (1.0)

34. AUDIENCE [cccc]hh

35.

36. JIM JEFFERIES it is that you can buy black and Asian people

37. AUDIENCE HHhhhh 
The comedian talks about an unrealistic situation, a father trying to replace his dead baby with another one and go unnoticed by the mother. Our present concern in the joke starts with line 13. The comedian says that it is easier to replace a black or an Asian baby. This claim receives enormous reaction in form of long-lasting laughter, cheering and clapping. The comedian apparently realizes that his sentence carried a (seemingly) unintentional perlocutionary effect, that is, black and Asian babies are easier to replace, because in his view black and Asian people appear to look similar among each other. The comedian repeatedly tries to stop people laughing and cheering, and appears quite annoyed that his joke has been interpreted as a racist one, so he explains what the real intention ought to be behind the utterance.

There are at least two possible scenarios in this joke. One, that Jim Jefferies thought of one probable perlocutionary effect of his utterance while analyzing his own joke prior to the performance. Based on concurrent news on Angelina Jolie and Madonna adopting black and Asian children, the comedian might have assumed that his audience would be able to connect his utterance with the news, and reveal the desired meaning. In line 13 the comedian implied one thing, but the audience understood something else. Jim Jefferies, presumably, did not think of the potential perlocutionary effect with the racist connotations understood by the audience. The comedian may have not assumed such an interpretation because he is not known to be racist. The reaction of the audience, however, revealed a supposedly unintentional perlocutionary effect.

The second plausible scenario is that Jim Jefferies was all along well aware of both illocutionary forces his utterance carried. He might have also known that the audience would understand the racist connotation first - that being the obvious one - which indeed caused enormous ovation. His getting annoyed and making the audience stop cheering may have been a well-planned stratagem of the routine in order to defend himself from later accusations for the racist joke. He may have wanted to treat the racist interpretation as the one he had nothing to do with, deliberately making it the audience's interpretation, although he planned on that understanding to happen. After making it clear that he has nothing to do with the racist interpretation, he introduced another one, which he could justify with Madonna and Angelina Jolie. If this is the case, he intended to keep the racist connotation of the joke as well as avoid being accused of racism at the same time, and as he could not rationalize racism, he looked for a different way of doing it.

The mind strives to disambiguate the elements of an utterance by selecting the meanings that are most appropriate and plausible in the given context. However, jokes insert a violation into this logic so that new isotopies can be created, the comprehension of which requires an effort. The perceiver has to understand the 
rules of communication within the context of the joke, and must seek the logic of the utterance that results in humor. A deictic term in everyday interaction must have a clear reference in order to be understood, and the reference has to respect other rules of communication (such as the Gricean maxims or the politeness maxims) for it to make sense. However, deictic terms that are used in jokes for humor purposes will refer to an unexpected element. Utterances in everyday interactions state one thing but may implicate something else, which makes sense in the given context. Implicatures in jokes are more complex, unexpected and they require a bigger effort to be understood. When a series of stimuli have been processed by the brain and the intended meaning has been understood, the perceiver tends to signal the end of the process by reacting to the performed utterance. This reaction is laughter if the joke results in humor perception. Laughter does not only signal comprehension, but also functions as a reward for the comedian and for the self for having been able to deduce the intended meaning and having found humor. If the stimulus is weak, too obvious, or if it does not require an effort, the reaction will also be weak with reduced or no humor perception. If the complexity of the processes has not resulted in detecting the violation (of any aspect of communication) in the joke, the perceiver will fail to see humor in it. Offensive stand-up comedy humor strives to maximize the number of stimuli that reach the perceiver's mind, yet at the same time tries to stay within the audience's comprehension level. The offensive layer cannot be built on a weak stimulus in a joke because the force carried by the joke's offensiveness will be bigger than the humorous force.

The one-liner "What is worse than biting into an apple and finding a worm? (Pause) Being raped." illustrates how the punch line neglects relevance in the given context, which is the opposite of what our brain does when it builds up the isotopy of a text, and introduces a new interpretation of the question, which makes it irrelevant according to the rules of communication, and so, it becomes a joke. If the question "What is worse than...?" is placed under the magnifying glass of pragmatics, it can be concluded that the impliciture left in the semantic meaning of the utterance is "What is worse than biting into an apple and finding a worm \{with relevance to the context of biting into an apple\}?" Humor plays with implicitures as well as with implicatures. Implicitures refer to what a sentence implicitly communicates. Laurence Horn $(2006,44)$ posits that not everything communicated can be derived as a Gricean implicature. To the sentence "John and Mary are married." Horn $(2006,44)$ adds in curly brackets what the sentence implicitly communicates: \{to each other\}. He argues that "it is truth-conditionally relevant, but neither can it be part of what is said, since it is felicitously cancelable: John and Mary are married, but not to each other." 
On the other hand, conversational implicature is a pragmatic phenomenon concerned with what is implied or folded in a conversation, which has to be unfolded by the addressees. With the sentence "John and Mary are married." one might implicate that the fact that Mary is pregnant is approved by the Church.

Taking into account the implicit content of the question in the previously introduced joke, one could finish the joke with the following punchline: "Finding half a worm because it means you've eaten the other half." However, respecting the rule regarding the implicit content results in a weak stimulus, also making the joke rather predictable. Edgy stand-up comedy humor cannot succeed unless there is a stronger, unexpected violation of the cooperative principle. The one-liner could also be finished by neglecting the implicit content, but without being immoral. By changing the punchline to "being robbed" the element of surprise is bigger and more rules of communication are violated. This is the point where the stand-up comedian can replace "robbed" with "rape" in order to add the element of edginess as the structural and pragmatic stimulus is now strong enough to balance the offensive nature of the joke. In fact, by adding the offensive layer, a series of other mechanisms can be observed, all of which stimulate the perceiver simultaneously. The punch-line "being raped" violates the Gricean maxim of manner because the answer deliberately makes the question ambiguous, violates the positive politeness maxim of sympathy because the answer fails to give high value to others' feelings by introducing the disturbing topic of rape, and the answer can be considered a face-threatening act that threatens the perceiver's positive face (carelessness towards someone's feelings). Furthermore, the strategy of on-record impoliteness is used, which means that damaging the hearer's face is intentional and straightforward, and the strategy of positive impoliteness is applicable, as well, because the joke introduces taboos.

The strength and the complexity of the stimuli are also highly affected by the performance of the comedian, who is fully aware of the conventions of the situation. Comedians use different strategies to increase the humorous effect of their acts. Timing is one such crucial component, and the effect of the stage persona's charisma can also be detected when analyzing an extract. Group dynamics in the audience, the status of the comedian in the public eye will also influence the perception of jokes.

\section{Conclusion}

Based on the above-elaborated summary of my research, it can be concluded that offense in stand-up comedy humor must be built on strong stimulus (possibly stimuli) that the perceiver can fully comprehend. This is owed to using multiple channels through which the perceiver can reveal all underlying mechanisms 
of the utterance. The audience must recognize the violations of any rule of communication or moral standard but, at the same time, has to manage to feel detached enough in order to allow humorous interpretations. This might happen due to high self-esteem, willing suspension of disbelief, by which the perceiver can assume (or endorse) the attitude of the offender for the duration of the joke. The closer the audience feel to the edge, the more humor they seem to perceive. However, once the elusive line is crossed, humor perception decreases and the sense of feeling offended emerges. The dividing line is highly subjective, and the extent to which one takes offense is directly proportional to the strength of one's subjective and affective moral commitment.

\section{Works Cited}

Allen, Steve. 1998. How to Be Funny: Discovering the Comic in You. Amherst, NY: Prometheus Books.

Attardo, Salvatore. 2000. Humorous Texts: A Semantic and Pragmatic Analysis. Povo: Youngstown State University.

Carr, Jimmy. 2009. Telling Jokes. Live at London's Bloomsbury Theater.

De Sousa, Ronald. 2002. "Emotional Truth". Aristotelian Society Supplementary Volume. Oxford: OUP.

Fenton, Andrew. 2016. "I don't rape, I just say bad things' argues Australia's most controversial comedian Jim Jefferies". News Corp Australia Network.

https://www.news.com.au/entertainment/i-dont-rape-i-just-say-bad-things-arguesaustralias-most-controversial-comedian-jim-jefferies/news-story/2855de9244456a-1486a 694354588dbb6 (2018. aug. 17.)

Gaut, Berys. 2007. Art, Emotion and Ethics. Oxford: OUP.

Grice, Paul. 1989. Studies in the Way of Words. Cambridge, MA: Harvard University Press.

Horn, Laurence R. \& Gregory Ward. 2006. A Handbook of Pragmatics. Oxford UK \& Malden MA, USA: Blackwell.

Jefferies, Jim. Bare. 2014. [Netflix special] Performed: Wilbur Theatre, Boston, Massachusetts.

Jefferson, Gail. 2004. "Glossary of transcript symbols with an introduction.” In Lerner G. ed. Conversation analysis: Studies from the first generation. 13-31. Amsterdam/Philadelphia: Benjamins.

Lasky, Natasha. 2015. "Are You Kidding? A Framework for Determining the Ethics of Jokes". https://roundtable.menloschool.org/issue22/2_Lasky_MS_Roundtable22_Fall_2015. pdf (2019. nov. 29.)

"Immoral." Merriam-Webster Unabridged Dictionary. https://www.merriam-webster.com/dictionary/immoral (2019. dec. 2.)

McIlvenny, Paul, Sari Mettovaara \& Ritva Tapio. 1993. "I Really Wanna Make You Laugh: Stand-up Comedy and Audience Response" Folia, Fennistica \& Linguistica: Proceedings of the Annual Finnish Linguistic Symposium. May 1992. 225-247. Tampere: Tampere University. 
Palmer, Jeremy. 1994. Taking Humour Seriously. London: Routledge.

Raskin, Victor. 1985. Semantic Mechanisms of Humor. Dordrecht: D. Reidel.

Smuts, Aaron. 2010. “The Ethics of Humor: Can Your Sense of Humor be Wrong?” Ethical Theory and Moral Practice. Vol. 13. Issue 3. 333-347.

Veatch, Thomas. 1999. "Humor is Affective Absurdity" tomveatch.com

http://www.tomveatch.com/else/humor/paper/node2.html. (2019. nov. 29.)

\section{Roland-Atila SABO}

\section{FAKTORI I USLOVI KOJI UTIČU NA PERCEPCIJU UVREDLJIVOG HUMORA}

Rad predstavlja deo jedne obimnije studije, doktorske disertacije autora, i daje pregled i ilustruje najvažnije faktore koji tako manevrišu iskaze da se percipiraju kao šaljivi i/ili uvredljivi u kontekstu izvedene, oštre stendap komedije. U radu su predstavljene osnovne teorije humora i teorije uvredljivog humora, kao i određeni pragmatički mehanizmi koji stoje iza procesa koji započinje iskazom a završava perlokucijskim efektom na publiku. Studija se bavi teorijama uvredljivog humora, konvencijama stendap komedije, pragmatičkim konceptima, kontrastima uvredljivog i nemoralnog, a sve ovo je dopunjeno kratkom psihološkom perspektivom, povezujući reakcije publike sa pojmom uvrede i nivoom samopoštovanja. Pragmatički uvid u faktore koji utiču na funkciju uvredljivog humora ukazuje na neophodnost snažnih, nekonvencionalnih i složenih podražaja koje publika percipira i razume, a na osnovu kojih se gradi uvredljivi sloj.

Ključne reči: uvredljivi humor, stendap komedija, pragmatika

\section{SZABÓ Roland-Attila}

\section{A SÉRTÖ HUMOR ÉRTELMEZÉSÉT BEFOLYÁSOLÓ TÉNYEZŐK ÉS FELTÉTELEK}

A dolgozat, amely egy nagyobb tanulmány (a szerző doktori értekezése) részét képezi, áttekinti és szemlélteti azokat a legfontosabb tényezőket, amelyek úgy alakítják a megnyilatkozásokat, hogy azok humoros és/vagy sértő hatást érjenek el az előadott, éles stand-up comedy kontextusában. A dolgozat bemutatja az alapvető humor- és sértőhumor-elméleteket, valamint bizonyos pragmatikai mechanizmusokat, amelyek a mögött a folyamat mögött állnak, amely egy megnyilatkozással kezdődik, és a közönségből kiváltott perlokúciós hatással végződik. A tanulmány a sértőhumor-elméletekről, a stand-up comedy konvencióiról, pragmatikai fogalmakról, a sértő és az erkölcstelen kontrasztjáról értekezik, mindezt pedig egy rövid pszichológiai perspektívával is kiegészíti, összekapcsolva az emberek reakcióit a sértés fogalmával és az önbecsülés szintjével. A sértő humor funkcióját befolyásoló tényezők pragmatikai számbavétele rámutat a közönség által érzékelt és érthető erős, nem konvencionális és összetett ingerek szükségességére, amelyek segítségével a sértő réteg megszerkeszthető. Kulcsszavak: sértő humor, stand-up comedy, pragmatika 